\title{
Conservation Management of Agriculture Land using Geospatial Approach (A Case Study in the Bone Watershed, Gorontalo Province, Indonesia)
}

\author{
Sri Maryati ${ }^{1 *}$, Sunarty Eraku ${ }^{1}$, and Muh $\mathrm{Kasim}^{2}$ \\ ${ }^{1}$ Geography Education Study Program, Department of Earth Science and Engineering, Faculty of Mathematics and Natural \\ Sciences, Univers itas Negeri Gorontalo, 96128 Indonesia \\ ${ }^{2}$ Engineering Geology Study Program, Department of Earth Science and Engineering, Faculty of Mathematics and Natural \\ Sciences, Universitas Negeri Gorontalo, 96128 Indonesia
}

\begin{abstract}
Bone Watershed is one of the major watersheds in Gorontalo Province. Bone watershed has a very important role for the people of Gorontalo Province. The role of Bone Watershed is mainly related to the providing clean water, producing oxygen, controlling flood, providing habitat for endemic flora fauna and other environmental functions. The role of Bone Watershed for the community's economic sector is also very important, the Bone watershed provides livelihood for surrounding communities includes fertile land resources for agriculture and plantations, forest products, and livestock feed. This research is important considering the Bone watershed has limited availability of land for agriculture and the high risk of natural disasters such as floods and landslides. Geospatial data includes topography map, landform map, soil map, integrated with field survey results and soil properties were analized to determine conservation management of agriculture land in the Bone Watershed, Gorontalo Province, Indonesia. The result of this study shows that based on soil properties and physical land characteristics, land use for agriculture should consider appropriate conservation techniques, land capability and respect to local wisdom.
\end{abstract}

\section{Introduction}

Bone Watershed is one of the major watersheds in Gorontalo Province. Bone watershed has a very important role for the people of Gorontalo Province. The role of Bone watershed is mainly related to the providing clean water, producing oxygen, controlling flood, providing habitat for endemic flora fauna and other environmental functions. The role of Bone Watershed for the community's economic sector is also very important, the Bone watershed provides livelihood for surrounding communities includes fertile land resources for agriculture and plantations, timber forest products, rattan, resin and livestock feed.

Bone Watershed also has its own characteristics with the existence of National Park Bogani Nani Wartabone in Bone Watershed which is the habitat of endemic flora and fauna such as Anoa, Maleo birds, and forest orchids. Area of National Park Bogani Nani Wartabone which belongs to Bone Watershed area is $73,477.12 \mathrm{Ha}$ or $70.65 \%$ of total watershed area. Bone Watershed sustainability must be maintained in an integrated manner considering the watershed is a complex system. Environmental damage from one part of the watershed will affect other parts of the watershed and lead to the possibility of natural disasters and other economic losses.
This study focuses on the management of conservation for agriculture in the Bone Watershed, Gorontalo Province. Environmental conservation should be implemented for environmental sustainability preserved and supports the concept of sustainable development. This becomes very important because the Gorontalo province in December 2016 was appointed as a conservation province by the Indonesia Minister of Forestry and Environment.

Similar to other regions in Gorontalo Province, Bone Watershed community choose corn commodities because corn is easy to be cultivated in a wide range of physical conditions of the land. Besides, corn has short growing period and is one of the staple foods other than rice for the people of Gorontalo. Agricultural management that considers environmental sustainability can improve agricultural productivity, increase community income and minimize opening of agricultural land in forest areas, including protected areas.

Human intervention in watershed management is important as there is interaction between human activities and natural process in watershed [1]. This is due to the increased human pressure on nature due to the increasing population which causes various development activities in watershed [2]. A good watershed management will have an impact on

\footnotetext{
Corresponding author: sri.maryati@ung.ac.id
} 
increasing people's incomes, increasing employment opportunities, reducing migration to cities, as well as reducing poverty [3].

The benefits of watershed management for the agricultural sector including the improvement of cropping patterns and provide better agricultural products [4]. The upland of watershed provide forestry products, livestock and fruits while the lowland of the watershed provide food crop [5]. The benefits of watershed management on agricultural land include increased agricultural productivity by increasing irrigated areas and soil conservation, crop diversification, high value crop planting and fodder availability. This is ultimately improves people livelihood [6].

This research aims to determine appropriate conservation management of agricultural land using geospatial approach in Bone Watershed, Gorontalo Province, Indonesia. This research utilizes various geospatial data, field survey, laboratory analysis, and determination of appropriate conservation management based on the consideration of land physical characteristics.

\section{Study Area}

The study area is Bone Watershed, as can be seen in Figure 1 located in Bone Bolango Regency, Gorontalo Province, Indonesia which covers an area of 1017.55 $\mathrm{km}^{2}$. Geographic coordinate of the study area is $0^{\circ} 23^{\prime}$ $48.26^{\prime \prime} \mathrm{N}$ to $0^{\circ} 42^{\prime} 18.354^{\prime \prime} \mathrm{N}$ and $123^{\circ} 3^{\prime} 45.522^{\prime \prime} \mathrm{E}$ to $123^{\circ} 32^{\prime} 56.235^{\prime \prime} \mathrm{E}$.

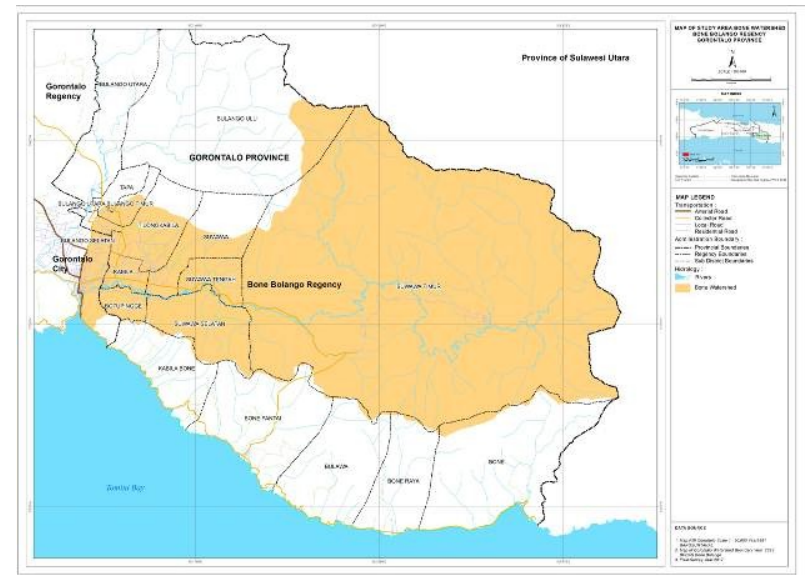

Fig. 1. Map of Study Area

Based on administrative boundaries, Bone Watershed is located in Bone Bolango Regency and Gorontalo City. There are 17 districts of Bone Bolango Regency and 6 Subdistricts of Gorontalo City which are included in Bone Watershed area. The largest subdistrict is Pinogu with an area of 47.398.25 Ha and Suwawa Timur which is 33,084.67 Ha. Based on Map Function Area, there are 5 types of area functions in Bone Watershed including national park, protected forest, production forest, limited production forest and non forest area.

\section{Methodologies}

This study used various spatial data include topographic map, landform map, soil map, climate map, geological map, and area function map. The unit of analysis used in this research is land unit. Land unit map was generated by overlaying landform map, slope map, and land map. Land unit map is presented in Figure 2.

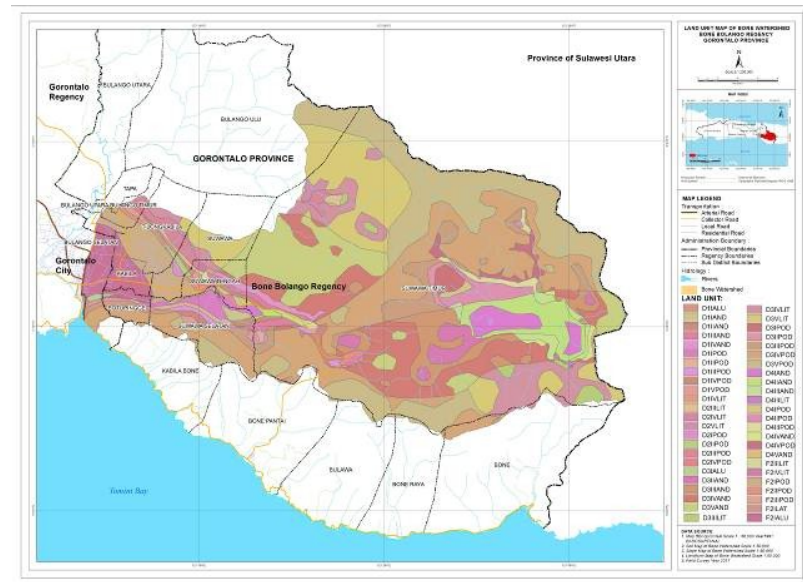

Fig. 2. Land Unit Map

Field survey was conducted to identify physical characteristics of land and soil sampling. Field survey results, soil properties, land capability, area function map, local wisdom characteristics were analyzed to determine conservation management of agriculture land in the Bone watershed, Gorontalo Province, Indonesia. This study is limited to areas that have status non protected forest and non the national park area.

\section{Research Finding and Discussion}

\subsection{Topography}

Topographic factors influence stability of land and determine velocity and volume of runoff. The main topographic factors are angle of slope, length of slope, and elevation. The longer the slope length is, the greater the volume of accumulated water is. The accumulated water flows in the land surface increases the erosive power. The greater slope angle is, the greater runoff velocity and also the greater ability of runoff to transport the soil particles are. Agriculture land located at higher elevation is more susceptible to erosion and landslides compared to the land located in the lowland area. Based on the slope map presented in Figure 3, the topography of the study area varies widely from flat, undulating, rolling, steep, and very steep. Based on the percentage, Bone Watershed is dominated by steep topography $(34.66 \%)$ and very steep topography (34.61\%). 


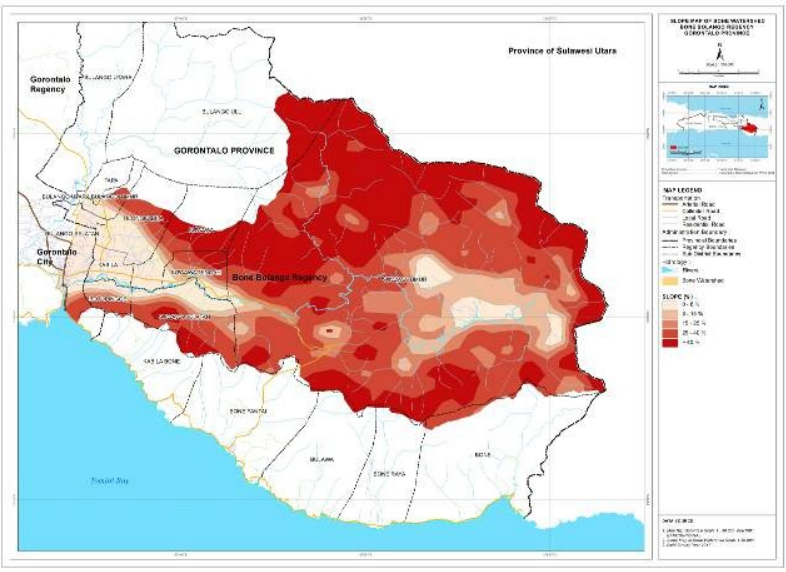

Fig. 3. Slope Map

\subsection{Landform}

Landform in the study area, as can be seen in Figure 4 Consist of alluvial plain, intermountain basin, the slope of denudasional hills, denudasional mountain, and denudasional hills. The landform became one of the important data inputs in this study because the landform is closely related to topography, parent material, and soil type hence it plays an important role in agricultural planning.

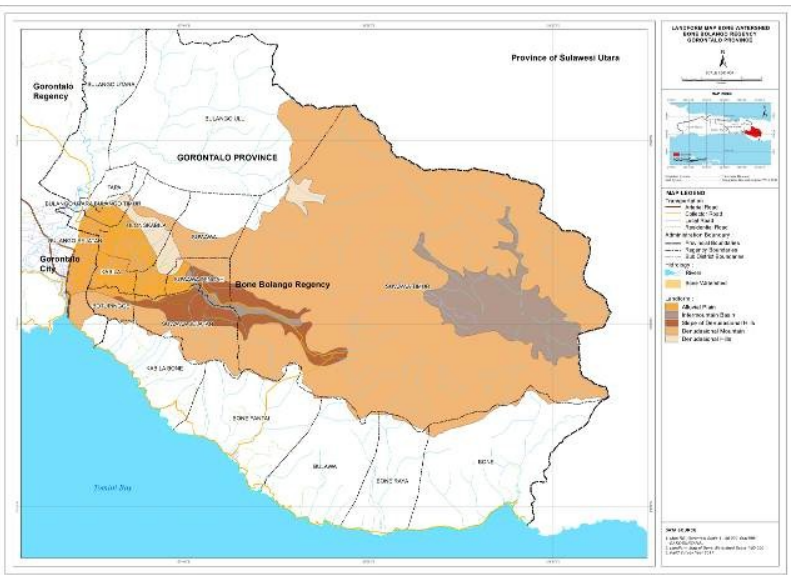

Fig. 4. Landform Map

\subsection{Soil Properties}

Chemical and physical properties of soil influence soil fertility and soil productivity. Thus soil properties are very important to determine suitable crop, appropriate soil treatment, proper soil improvement, and proper amount of fertilizer. Analysis of soil properties provided important information of soil condition both chemical and physical properties. The soil properties can be improved and maintained to increase the quality of soil by adding organic matter, adding appropriate amount and type of fertilizer, stabilizing topsoil against soil erosion and water detachment, and ripping to increase soil porosity.

Based on soil map, soil types in the study area include alluvial, litosol, podsolic and andosol. Field survey results showed soil depth in the study area varies from
$25-40 \mathrm{~cm}, 40-60 \mathrm{~cm}$, and $>60 \mathrm{~cm}$; soil texture of top soil include clay, sandy clay, sandy clay loam; percent of coarse material $<5 \%$ and $5-15 \%$. Related to risk hazard, generally no risk and low for flood and erosion. Some areas which has steep slope has severe erosion.

\subsection{Land Capability}

Land capability analysis is conducted to evaluate the potency of land for sustainable long term use. Result of land capability analysis can be used to support decision making for sustainable development in agriculture sector. Land capability assessment is used to determine land management to prevent land degradation both longterm conservation and type of land utilization[7]. Land capability analysis utilize topography data, soil properties data, and risk hazard data. Result of land capability in this study is presented in Figure 5.

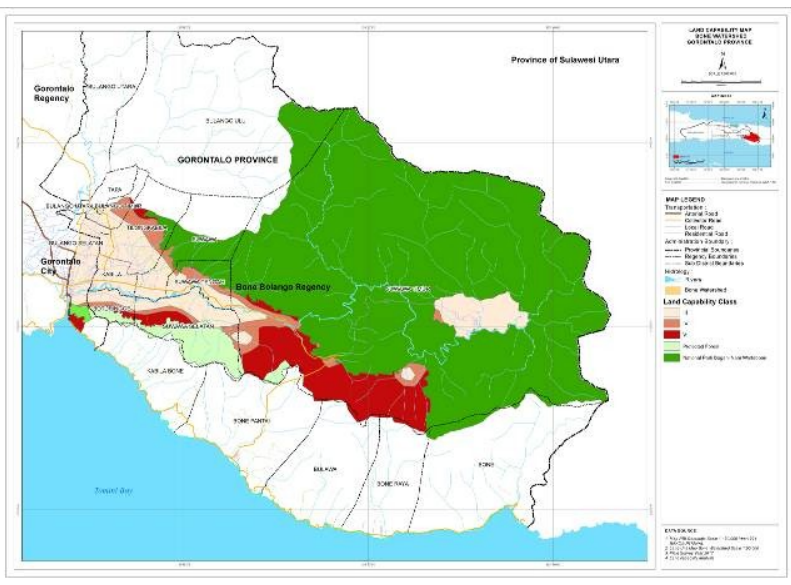

Fig. 5. Land Capability Map

Based on Figure 5, class of land capability in the study area consist of 3 class : Class III, Class IV, and Class VI. The study area is dominated by land capability Class III $(51.39 \%)$, followed by Class VI $(33,44 \%)$, and Class IV $(15.17 \%)$.

\subsection{Conservation Management}

Referring to result of land capability analysis, the study area has 3 class of land capability : Class III, Class IV, and Class VI. Land classified in Class III and Class IV can be utilized for agriculture with moderate and high conservation effort. Whereas land categorized in Class VI could not be used for cultivation, this land may be utilized for grazing or plantation. Type of limiting factor for class VI is topography condition (steep slope). Topographic conditions in steep slope land are natural factors that are difficult to improve in conservation, because it will change the landscape that may cause negative impacts to the environment such as erosion, landslides and land degradation triggering. Hence, class VI should be a forest or grazing land.

The limiting factors for class III and class IV are soil drainage, soil depth, soil texture, slope, and \% of coarse material. These limiting factors can be treated by soil 
improvement and soil conservation. Soil improvement according to the limiting factors will improve the capability class, the use for agricultural land will be productive and sustain. Topographic factors as a limiting factor in classes III and IV can be overcome by the selection of appropriate conservation techniques namely vegetative techniques, mechanical techniques, or combined both techniques.

\section{Conclusions}

The results of this study are expected to be the basis for decision making and direction in the land utilization for agriculture in the Bone Watershed. Utilization of land for agricultural areas can be carried out on land that has the capability class III and class IV with appropriate soil conservation efforts and respect to local wisdom. The selection of agricultural commodities can consider the suitability of land for optimal productivity and land can be used for sustainable agriculture.

\section{Acknowledgements}

The authors' wish to express their deepest gratitude to Directorat General Higher Education, Ministry of Research, Technology and Higher Education Indonesia for research funding. The authors also acknowledge Rector of Universitas Negeri Gorontalo, Head of Institute for Research and Community Services Universitas Negeri Gorontalo, and Dean of Faculty of Mathematics and Sciences for permit and support to participate and to attend The 2nd International Conference on Energy, Environment and Information System (ICENIS).

\section{References}

1. X. Cai, R.Vogel, R. Ranjithan, Journal of Water Resources Planning and Management 139 (5) (2013)

2. A.Mirchi, D.Watkins Jr, K.Madani, Modeling for Watershed Planning, Management, and Decision Making (Nova Science Publishers, Inc, 2009)

3. P.Pathak, A.K. Chourasia, S.P.Wani, R.Sudi, Journal of Water Resource and Protection 5 (2013).

4. S.S.Nerkar, A.Pathak, C.S.Lundborg, A.J. Tamhankar, International Journal of Environmental Research and Public Health 12 (2015)

5. G.B.Thapa. Integrated Watershed Management : Basic Concepts and Issues. In Human Settlement Development ( Eolss Publishers Co.Ltd, 2009)

6. S.P.Wani, KH.Anantha, TK. Sreedevi, R.Sudi, SN. Singh, and M. D'Souza, Journal of Sustainable Watershed Science and Management 1(1) (2011)

7. T. Notohadiprawiro, Kemampuan dan Kesesuaian Lahan: Pengertian dan Penetapannya, Lokakarya Neraca Sumberdaya Alam Nasional, DRN Kelp. II- BAKOSURTANAL, (1991). 